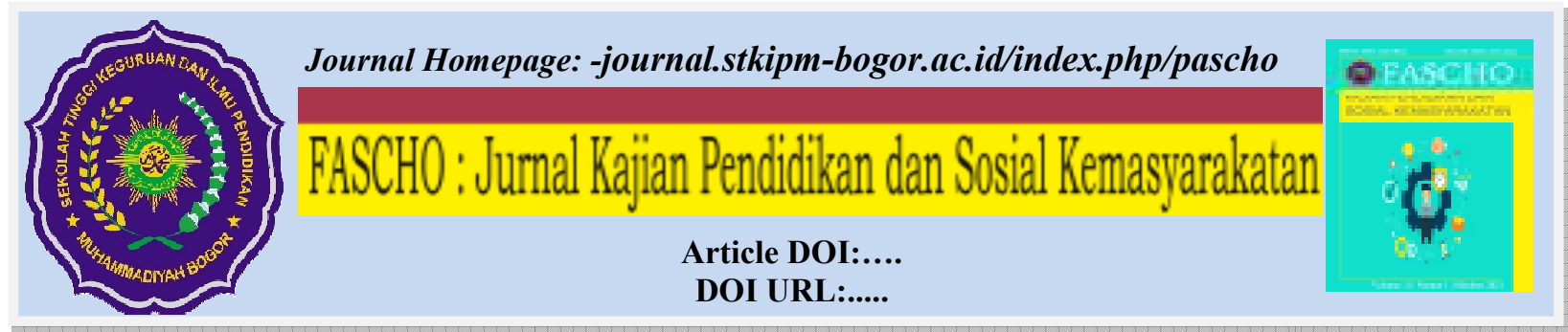

\title{
DIDACTIC LITERATURE LESSON ON PHILOSOPHICAL NOVEL SOPHIE'S WORLD
}

\author{
SOFIATIN \\ STKIP Muhammadiyah Bogor Lecturer \\ e-mail: osofiatin@gmail.com
}

\section{Manuscript Info}

Manuscript History

Received: 03 April 2021

Final Accepted: 01 Oktober 2021

Published: 10 Oktoberl 2021

Key words:- novel Dunia Sophie, literature learning, philosophical learning

\begin{abstract}
Literature in written works comes to give aesthetic value and entertainment to the readers. It also has an educational function in purpose to change the way people think. One of which is a novel written by Jostein Gaarder entitled Sophie's World. Based on didactical value, this novel is categorized as Hybrid literature. Hybrid literature is combined with didactic literature and imaginative literature. Didactically, this novel gives philosophical lessons. Meanwhile imaginatively, it explores readers' imagination. Sophie's World was written in simple language and plot that can easily be understood by the readers to learn about philosophy in an easy way. Its progressive plot and its writing style, which tells the story inside the story, make this novel still interesting to read because of its suspension and puzzle on its story. This novel is studied by using a descriptive qualitative method with a content analysis approach, conducted by describing the didactical literature of this novel, analysing the content or didactic expression, and analysing the language use. This novel is highly suggested to be used as learning media for philosophical course taught in Higher Education and as learning media in teaching literature. Besides, the novel Sophie's World is good to be read by everybody to enrich their philosophical knowledge..
\end{abstract}

\section{Pendahuluan}

Sastra sebagai salah satu karya seni adalah sesuatu yang dapat dinikmati setiap orang melalui beragam pancainderanya. Karya sastra juga memiliki sebuah tujuan yang ingin dicapai oleh karya sastra itu sendiri, salah satunya adalah menjadikan sastra sebagai media penyampaian pesan dari pengarang kepada pembaca seperti dapat menyampaikan sebuah ilmu pengetahuan lain untuk memperkaya wawasan pembaca. Filsafat sebagai inti ilmu 
pengetahuan, saat ini semakin mendapat tempat di hati masyarakat terutama jika dituangkan ke dalam karya sastra berbentuk novel.

Kita ketahui bahwa sebelumnya ilmu tentang filsafat di belahan bumi manapun dipelajari melalui buku-buku teks, kitab, atau buku pengayaan yang jumlahnya tak terhingga. Namun pada abad 21, pembelajaran filsafat telah menggunakan kemasan baru yang lebih menarik, yaitu melalui karya sastra berbentuk novel. Memang belum banyak, namun sejak novel filsafat Dunia Sophie (2017) karangan Jostein Gaarder muncul dan merebak di seluruh dunia, novel best seller ini banyak diikuti oleh pengarang novel lainnya dengan memproduksi cerita yang bertema sama. Apalagi Gaarder memproduksi kembali novel dengan bertema sama yang berjudul Dunia Ana, keberlanjutan cerita dari novel Dunia Sophie.

Langkah Gaarder memperkenalkan filsafat melalui hasil karya-karya novelnya, telah menjadi hal mengagumkan dalam dunia sastra dan filsafat. Dunia sastra telah mampu memberikan solusi dengan mengangkat bidang ilmu filsafat melalui caranya bercerita sebagai pembelajaran yang lebih efektif, mudah, ringan, dan menyenangkan bagi pemabca. Tak dipungkiri bahwa pada umumnya orang lebih suka membaca buku cerita dibandingkan membaca buku teks. Dalam hal ini, filsafat sebagai sebuah bidang ilmu selalu dipandang cukup sulit untuk dipelajari orang. Akan tetapi, melalui metode bercerita, ilmu filsafat tidakl lagi menjadi sulit untuk dipelajari. Begitu pula dengan cara Gaarder bercerita membuat sebuah karya sastra semakin mendapatkan tempat istimewa dalam tataran bidang ilmu lainnya, dalam hal ini sebagai jalan mudah untuk mengimplementasikan pembelajaran filsafat kepada setiap orang.

Sebagai novel serius yang populer, Dunia Sophie adalah novel yang dapat menuntun para pemula agar dapat mempelajari filsafat dengan cara yang mudah. Novel ini membuat pembaca tidak menyadari bahwa mereka sedang mempelajari ilmu filsafat. Novel ini juga, membuat para pembaca menjadi tertarik terhadap ilmu filsafat untuk, dan tertantang untuk terus menigkuti alur cerita hingga habis. Adanya teka-teki, ketegangan (suspense), cara penyampain yang dapat dicerna oleh pemikiran pembaca remaja dan dewasa, serta alur cerita maju dengan gaya pengisahan bercerita di dalam cerita, menjadikan novel ini tidak kehilangan greget di mata pembaca. 
Ada yang lebih penting dari sekedar alur cerita, yakni pemikiran-pemikiran filsafat yang dituangkan Gaarder melekat bersama pengisahan tokoh kedua di dalam novel ini. Memang Gaarder masih menginterpretasikan filsafat yang bersifat umum. Oleh karena itu, alangkah tepatnya jika buku novel ini dibaca oleh para pemula yang tertarik dengan dunia filsafat. Sebagai contoh, di awal cerita pembaca sudah disuguhi kalimat tanya, "siapa kamu?", yang membuat Sophie Amundsend, tokoh gadis berusia 14 tahun tak dapat berhenti memikirkan jawabannya. Pertanyaan-pertanyaa singkat yang dikirim orang tak dikenal Sophie yang dikemudian hari diketahui bernama Albert Knox, telah memberikan segudang pengetahuan filsafat bagi Sophie. Pemikiran-pemikiran Democritus, Socrates, Plato, Aristoteles, Decartes, hingga Freud, telah mampu mengubah pemahaman seorang gadis belia seperti Sophie tentang kehidupan, merupakan hal tak biasa untuk gadis seusianya.

Sebagai sebuah karya sastra, novel Dunia Sophie dikategorikan sastra hibrida. Sastra hibrida yaitu sastra yang di dalam sebuah karya mengandung perpaduan antara sastra didaktis dengan sastra imajinatif. Dalam hal ini, ilmu filsafat yang bersifat konseptual dituangkan ke dalam konten cerita yang juga sarat dengan imajinasi pengarang. Sastra didaktis, menurut Abrams (1999: 65),

intended to give instruction," is applied to works of literature that are designed to expound a branch of knowledge, or else to embody, in imaginative or fictional form, a moral, religious, or philosophical doctrine or theme. Such works are commonly distinguished from essentially imaginative works (sometimes called "mimetic" or "representational") in which the materials are organized and rendered, not in order to enhance the appeal of the doctrine they embody, but in order to enhance their intrinsic interest and their capacity to move and give artistic pleasure to an audience [bertujuan untuk memberikan pengajaran, diterapkan terhadap karya sastra yang didesain untuk menjelaskan suatu cabang pengetahuan atau lainnya untuk mewujudkan tema atau doktrin moral, agama, atau filsafat dalam bentuk fiksional atau imajinatif. Karya-karya sastra didaktis umumnya dibedakan dari karya sastra imajinatif (kadang-kadang disebut mimetik atau representasional), yaitu karya sastra yang materinya disusun dan ditampilkan, tidak untuk meningkatkan daya tarik pada doktrin yang diwujudkan, tetapi untuk meningkatkan minat intrinsik dan kapasitasnya untuk menggerakkan dan memberikan kenikmatan artistik terhadap pembaca].

Senada dengan pendapat Sumiyadi (2017: 4) yang menyatakan bahwa sastra imajinatif adalah “...satra yang menonjolkan kualitas intrinsik atau kenikmatan artistik." 
Di satu sisi, Dunia Sophie begitu banyak memberikan pembelajaran tentang filsafat. Di sisi lainnya, novel ini menghadirkan unsur-unsur intrinsik dan ekstrinsik yang tak kalah penting untuk dicermati. Penjelasan-penjelasan tentang ilmu filsafat disusun secara sistematis melalui muatan yang bersifat konseptual ilmu. Meskipun pada akhirnya bagian-bagian dari ilmu filsafat banyak dialirkan pengarangnnya ke dalam ruang imajinasi pembacanya. Namun, pada akhirnya hasil kolaborasi antara sastra didaktis dan imajinatif dalam novel Dunia Sophie telah menghasilkan suatu perpaduan cerita bernuansa saintifik yang sangat menarik dan berbobot.

Menurut Clara Reeve (Wellek, 1989: 282),

novel adalah gambaran dari kehidupan dan perilaku yang nyata, dari zaman pada saat novel itu ditulis. Bentuk tulisan naratif ini diungkapkan oleh penulis bukan hanya mengandalkan tema tetapi dengan menyajikan keunikan unsur intrinsik." seperti alur, penokohan, atau latar yang membuat pembaca menjadi penasaran.

Sementara, Soemardjo (1988: 37) menyebutkan "novel adalah bentuk sastra yang paling populer di dunia. Bentuk sastra ini paling banyak dicetak dan paling banyak beredar, lantaran daya komunitasnya yang luas pada masyarakat." Jika novel merupakan sebuah media, maka novel dapat digunakan sebagai media hiburan sekaligus media pembelajaran bagi pembaca. Oleh karena itu, novel dapat dikatakan sebagai karya sastra populer.

Pembelajaran adalah sebuah perubahan pada diri seseorang dikarenakan pengalaman yang diterimanya. Pembelajaran juga tiada lain untuk memberikan perubahan terhadap cara berpikir dan bertindak seseorang melalui pengalamannya agar menjadikan dirinya menjadi lebih berkembang kea rah yang positif. Dalam hal mengasah suatu keterampilan, dan mengenai bagaimana keterampilan itu diperoleh, tentu harus melalui tahapan atau proses pengajaran (Slavin, 2003: 138). Cara pembelajaran seperti ini yang disebut sebagai kualitas proses. Kualitas proses ini yang pada akhirnya mampu membentuk pengalaman seseorang menjadi pembelajar yang baik, termasuk pembelajaran atas pembacaan karya sastra novel.

Sastra adalah sebuah karya seni, karena itu sastra mempunyai sifat yang sama dengan karya seni yang lainnya, seperti seni suara, seni lukis, seni pahat, dan lain-lain (Semi, 1989: 39). Sementara Kamus Besar Bahasa Indonesia Edisi Kelima (2017, hlm. 1470) 
mengartikannya sebagai sas.tra $n 1$ adalah "bahasa (kata-kata, gaya bahasa) yang dipakai di kitab-kitab (bukan bahasa sehari-hari).” Dalam Kamus Istilah Sastra (Zaidan dkk, 2004, hlm. 181) mengartikan kata sastra sebagai “ $U$. tulisan dalam arti yang luas. Umumnya sastra berupa teks rekaan, baik puisi maupun prosa yang nilainya tergantung pada kedalaman pikiran dan ekspresi jiwa." Berdasarkan pada seluruh pengertian di atas dapat disimpulakan bahwa sastra adalah sebuah tulisan atau teks apapun itu yang bersifat imajinatif serta memiliki nilai atau arti berdasarkan hasil pemikiran dan ekspresi jiwa manusia. Oleh karena itu, Pembelajaran sastra dapat difahami sebagai sebuah kegitan bersastra dengan menggunakan metode yang sistematis. Dalam arti, pendekatan atau cara yang digunakan dalam pembelajaran sastra akan mempermudah pengajaran sastra di kelas sehingga dapat mengunggah minat siswa untuk mempelajari sastra dengan efektif dan menyenangkan.

Sebelum mengenal apa itu konsep filsafat, ada baiknya kita banyak membaca serta mendengarkan hal-hal yang berkaitan dengan filsafat. Atau dengan cara kita mengalami dan mengamati gejala-gejala filsafat dalam kehidupan nyata. Dengan cara seperti itu, kita akan merenungi apa yang kita alami dan amati yang pada akhirnya kita mampu menarik sebuah kesimpualan tentang konsep filsafat. Sebagaimana menurut Poedjawiyatna (1974: 1) bahwa "kata filsafat berasal dari kata Arab yang berhubungan rapat dengan kata Yunani ialah philosophia. .... Jadi menurut namanya saja filsafat boleh diartikan ingin mencapai pandai, cinta pada kebijakan (lihat juga Windelband, 1958 : I: 1)." Karena itu, novel Dunia Sophie yang dikategorikan sebagai novel filsafat, di dalamnya terkandung teks-teks dengan tuturan bijak serta ilmu pengetahuan dari penulisnya. Pemahaman mendalam terhadap bidang ilmu filsafat yang kita pelajari, akan membuat kita menemukan banyak pemahaman tentang kehidupan.

Novel ini akan dikaji melalui pedoman butir-butir analisis kedidaktisan yang telah dihimpun dari berbagai sumber. Baik isi berupa teks novel, konteks novel secara lisan maupun tulisan. Kedidaktisan novel Dunia Sophie dikaji dengan teknik analisis dengan cara mengungkapkan atau teknik analisis isi ungkapan dan dengan teknik analisis penggunaan bahasa. Hasil penelitian ini dapat dimanfaatkan sebagai media pembelajaran mata kuliah filsafat dan mata kuliah sastra. Selain itu, novel Dunia Sophie sangat baik dibaca oleh siapapun untuk memperkaya wawasan filsafat bagi para pembacanya. 


\section{Metode}

Metode penelitian ini, menggunakan desain kualitatif deskriptif analisis isi dengan cara mengungkap kedidaktisan sastra, menganalisis isi/ ungkapam kedidaktisan, dan menganalisis penggunaan bahasa. Sumber data penelititan ini adalah novel Dunia Sophie karangan Jostein Gaarder. Sumber data penelitian ini adalah berbentuk data teks isi novel. Teknik pengumpulan data dengan cara membaca dan mencatat teks-teks yang mencerminkan kedidaktisan sastra dalam karya novel. Untuk mengkaji karya sastra novel, disusun sebuah pedoman analisis kedidaktisan karya sastra. Adapun pedoman analisis kedidaktisan karya sastra novel yang digunakan oleh peneliti dihimpun berdasarkan berbagai sumber (dalam Sumiyadi, 2015: 6). 


\begin{tabular}{|c|c|}
\hline Butir-butir analisis & Deskripsi analisis \\
\hline $\begin{array}{l}\text { - Cara } \\
\text { menguungkapkan } \\
\text { kedidaktisan }\end{array}$ & $\begin{array}{l}\text { - Teknik pengungkapan : menelaah teknik pengungkapan karya sastra novel. Acuan: } \\
\text { struktur faktual novel, yaitu alur dan pengaluran, tokoh dan penokohan, latar- } \\
\text { tempat, waktu, sosial, dan suasana (Stanton, 2007). }\end{array}$ \\
\hline $\begin{array}{ll}\text { - Isi/ungkapan } \\
\text { kedidaktisan }\end{array}$ & $\begin{array}{l}\text { - Menemukan kesesuaian isi/ungkapan karya sastra/film dengan tujuan pendidikan } \\
\text { nasional. Acuan: UUSPN No. } 20 \text { Tahun 2003. Butir tujuan pendidikan nasional } \\
\text { terhadap karya sastra diharapkan berisi materi yang dapat mengembangkan potensi } \\
\text { pembaca untuk memiliki: } \\
\text { - kekuatan spiritual keagamaan yang dapat meningkatkan keimanan, ketakwaan, } \\
\text { dan berahlak mulia } \\
\text { - kekuatan spiritual keagamaan yang dapat meningkatkan keimanan, ketakwaan, } \\
\text { dan berakhlak mulia } \\
\text { - sehat jasmani } \\
\text { watak /Kepribadian yang bermartabat, mandiri, kreatif, demokratis, tanggung } \\
\text { - kecerdasan/berilmu } \\
\text { - keterampilan sebagai bekal kecakapan hidup } \\
\text { Menemukan dimensi budaya yang termuat dalam karya sastra/film. Acuan: dimensi } \\
\text { budaya yang lengkap terdiri atas bahasa, ilmu pengetahuan, profesi/pekerjaan, } \\
\text { teknologi, seni, sistem/organisasi sosial, dan religi/agama (Koentjaraningrat, 2015) } \\
\text { - Menemukan dimensi pengetahuan yang termuat dalam karya sastra. Acuan: dimensi } \\
\text { pengetahuan yang lengkap terdiri atas pengetahuan faktual, konseptual. prosedural, } \\
\text { dan metakognitif (Anderson dan Krathwohl, 2010) } \\
\text { Menemukan pengetahuan atau ilmu pengetahuan yang menjadi sumber } \\
\text { masalah/konflik dan solusi yang diberikan. Acuan: ilmu pengetahuan dapat mengacu } \\
\text { pada ilmu-ilmu sains (metematika, fisika, biologi, kimia, dsb.), sosial (antropologi, } \\
\text { sosiologi, ekonomi, geografi, sejarah, dsb.), dan humaniora (linguistik, sastra, } \\
\text { filsafat, dsb) (dalam Anshari, 1985) }\end{array}$ \\
\hline $\begin{array}{l}\text { Penggunaan } \\
\text { bahasa }\end{array}$ & $\begin{array}{l}\text { Menelaah bahasa yang digunakan pengarang. Acuan: karya sastra/film menggunakan } \\
\text { bahasa Indonesia standar (mengikuti kaidah struktur/gramatika bahasa Indonesia, EyD, } \\
\text { dan kosakata baku), kecuali dialog tokoh disesuaikan dengan konteks penggunaannya } \\
\text { agar komunikatif dan dialogis. }\end{array}$ \\
\hline
\end{tabular}




\section{Pembahasan}

Pengkajian kedidaktisan terhadap novel Dunia Sophie berdasarkan pada pedoman analisis kedidaktisan yang sudah tersedia (dalam Sumiyadi, 2015: 6). Isi novel dikaji dengan; cara mengungkapkan, analisis isi ungkapan, dan analisis penggunaan bahasa. Dalam hal ini, peneliti mencoba menggali kedalaman kandungan kedidaktisan karya sastra novel Dunia Sophie (2017) karangan Jostein Gaarder

\section{- Cara Mengungkapkan Kedidaktisan Sastra}

Novel Dunia Sophie merupakan novel filsafat barat yang dikarang oleh Jostein Gaarder dengan ketebalan isi 785 halaman. Di Indonesia novel ini diterbitkan oleh penerbit Mizan yang telah melampaui edisi ketiga - cetakan II di bulan Agustus 2017. Novel ini dialihbahasakan ke dalam bahasa Indonesia dengan menggunakan teknik pengungkapan alur maju. Meskipun demikian, ketebalan halaman dan alur maju tidak membuat novel ini tidak kehilangan greget pembacanya sampai akhir cerita. Melalui suspense pada setiap bagian, disertai dengan berbagai teka-teki, novel ini memberikan rasa penasaran bagi pembaca hingga sangat disayangkan apabila tidak habis membacanya sampai akhir cerita.

Pakar hukum serta pakar filsafat, Frans Magnis Suseno memberi testimoni pada sampul depan buku "Anda ingin tahu apa filsafat, tetapi selalu tidak sempat, terlalu kabur, abstrak, susah, dan bertele-tele. Bacalah buku manis ini di mana Sophie anak putri 14 tahun, menjadi terpesona karenanya." Pernyataanya tersebut memberikan satu petunjuk kepada kita bahwa buku ini sangat penting dan layak dibaca oleh siapapun. Buku ini bisa dijadikan sebagai acuan untuk pembelajaran filsafat bagi pemula dengan cara yang mudah dan menyenangkan.

Selain pendapat para ahli yang menegaskan bahwa buku ini merupakan karya sastra yang dapat membelajarkan filsafat kepada pembaca pemula, isi buku ini mengungkapkan dengan jelas kalimat-kalimat Gaarder yang mencerminkan kedidaktisan dari ilmu filsafat. Contohnya pengungkapan kedidaktisan pada kalimat surat kaleng yang diterima Sophie (Gaarder, 2017: 46) seperti "Bukankah pernah kukatakan bahwa satu-satunya yang kita 
butuhkan untuk menjadi filosof yang baik adalah rasa ingin tahu?" Di teks ini, Sophie menunjukkan sebagai remaja belia (14 tahun) yang sudah besar keingintahuannya tentang dunia filsafat yang bagi remaja seusianya bukan sebuah pengetahuan yang mudah untuk dicerna dengan pemikiran. Teks ini memberikan nilai didaktis bagi pembacanya.

Teknik pengungkapan karya sastra menurut Stanton (2007) adalah menelaah teknik pengungkapan karya sastra/film yang mengacu kepada struktur faktual novel, yaitu alur dan pengaluran, tokoh dan penokohan, latar-tempat, waktu, sosial, dan suasana. Adapun, teknik penyajian kedidaktisan menurut Schunk (2012) yaitu "menelaah prinsipprinsip kedidaktisan/pendidikan/pengajaran dalam karya sastra/film. Acuan untuk penyampaian pengetahuan disajikan secara logis, sistematis, sistemis, fokus, dan kontekstual." Sementara teknik penggunaan bahasa adalah menelaah bahasa yang digunakan pengarang, acuan: karya sastra/film menggunakan bahasa Indonesia standar (mengikuti kaidah struktur/gramatika bahasa Indonesia, EyD, dan kosakata baku), kecuali dialog tokoh disesuaikan dengan konteks (Sumiyadi 2015: 16).

\section{Teknik pengungkapan karya sastra}

Sebagai sebuah karya novel filsafat yang sangat terkenal, novel Dunia Sophie tak terlepas dari teknik pengungkapan yang berhubungan dengan unsur intrinsik sastra. Novel ini menggunakan teknik alur maju. Pengarang menggunakan gaya bercerita di dalam cerita. Ketebalan halaman dan unsur alur maju dalam novel ini, tidak kehilangan greget-nya, sehingga tidak membuat jenuh pembaca hingga akhir cerita. Adanya suspensis sepanjang alur cerita, pembubuhan ragam teka-teki, pengisahan sejarah filsafat yang runtut, ungkapan filosofi-filosofi yang manis, kebudyaan yang luar biasa, penjelasan tentang sejarah ilmu pengetahuan dari berbagai belahan dunia, diceritakan dengan ringan oleh pengarang melalui tuturan tokoh ceritanya.. Novel ini bertema ilmu pengetahuan, namun menantang pembaca untuk membacanya hingga akhir cerita, cepat atau lambat.

Pengaluran cerita novel ini dimulai dari perkenalan Sophie kepada dunia filsafat melalui pertanyaan dalam sebuah surat kaleng yang ditujukan kepada Sophie. Pertanyaan 
"Siapa kamu" dalam isi surat kaleng, membuat dirinya mencari-cari jawaban yang mengarah kepada dunia filsafat.

Sebagai tokoh utama, Sophie Amundsend dilukiskan Gaarder adalah seorang gadis berusia 14 tahun dengan pemikiran kritis dan cerdas. Dia selalu berupaya keras untuk menuntaskan berbagai permasalahan yang ia temui dan hadapi dengan mencari solusi yang mengarah pada pemahaman filsafat. Yang tak kalah menarik adalah Alberto Knox sebagai tokoh kedua, filosof muda yang misterius namun humanis, telah banyak menanamkan pemahaman filsafat terhadap Sophie dalam surat-surat kaleng yang dibuatnya. Kehadiran tokoh Ibu, Ayah, Joana, serta Hilde, Sang Major, ikut melengkapi alur cerita dengan dengan keragaman karakter sesuai ciri khas masyarakat Norwegia yang moderat tradisional. Teknik Penokohan terhadap Sophie, Alberto Knox, Hilde, Ibunya, Ayahnya, Joana, dan Sang Major, digambarkan melalui teks lisan dan tulisan yang dapat dicermati pembaca hingga akhir cerita. Tokoh dan penokohan cerita dapat ditangkap melalui deskripsi citra tokoh secara fisik, sosial, dan psikis.

Lebanon, Athena, dan Norwegia merupkan latar tempat yang menghubungkan kejadian dari tokoh yang satu ke tokoh lainnya. Sophie, Ibunya, Joana, dan Hilde, menjalani kehidupannya di Norwegia. Alberto Knox dengan tiga kehidupannya yakni di Norwegia, Athena, dan Libanon. Sementara ayah Sophie, ia telah menjalani kehidunnya selama beberapa tahun di Libanon sebagai pasukan khusus PBB. Setiap latar tempat ikut mewarnai terhadap latar waktu di pagi hari, siang hari, sore hari, dan malam hari. Sementara untuk latar suasana digamparkan anatara tenang dan mencekam. Suasana tenang ketika berada di tempat yang sepi seperti di kebun, hutan, atau danau. Sementara suasana mencekakan dapat digambarkan ketika Sophie mengalami rasa penasaran yang berkepanjangan terhadap sosok misterius yang sering mengirimkannya surat kaleng, dan Sophie berupaya mati-matian membuktikan sesosok misterius tersebut.

Pengisahan dalam novel ini menggunakan sudut pandang orang ketiga dengan menyebutkan semua nama tokohnya, seperti Sophie, Hilde, atau Alberto. Sudut pandang sebagai penanda seorang pengarang menempatkan dirinya terhadap cerita yang dikarangnnya, dan di dalam novel Dunia Sophie, sang pengarang menjadikan dirinya sebagai orang ketiga. 
Untuk pengungkapan kedidaktisan karya sastra diawali ketika Sophie menerima surat misterius dari kotak surat di depan rumahnya yang isinya berupa pertanyaan “siapakah kamu?” (Gaarder, 2017: 28). Sebuah pertanyaan singkat namun butuh jawaban yan cukup pangjang. Pertanyaan ini membuat Sophie mulai berpikir tentang hakikat dirinya sebagai manusia. Gaya penceritaan Gaarder atas kebingungan-kebingungan Sophie atas pertanyaan pertama sampai dengan ke pertanyaan berikutnya, telah menghasilkan pengungkapan yang didominasi kalimat-kalimat mencerminkan pemikiran Sophie dalam upayanya menemukan jawaban atas bebagai pertanyaan si pengirim surat kaleng.

Teknik pengungkapan lain yang dibuat Gaarder adalah teknik bercerita di dalam cerita. Si penulis surat juga selalu bercerita kepada Sophie tentang filsafat dan sejarahnya yang dimulai dari filsafat alam (masa perkembangan filsafat) hingga sampai ke filsafat abad modern. Meskipun alur yang dibuat Gaarder bukan alur kilas balik, namun pengisahan alur maju membuat pembaca dapat dengan seksama mengikuti alur ceritanya hingga habis. Kemudian, pembaca mendapatkan ketegangan dan kejutan pada setiap penciptaan konflik antara Sophie dengan Ibunya, Albert Knox si pengirim surat, dan bersama temannya, Joana.

\section{Penyajian Kedidaktisan}

Secara konteks, novel Dunia Sophie merupakan novel filsafat yang dapat dicirikan melalui kepribadian Sophie yang serba ingin tahu tentang banyak hal. Selain sering mempertanyakan banyak hal mengenai gejala-gejala yang tak biasa dipikirkan remaja pada umumnya, ciri lainnya ialah dengan siapa Sophie mulai berteman, dengan siapa Sophie sering berkomunikasi, dan seperti apa keteratarikan Sophie terhadap filsafat. Kelogisan lain sebagai novel filsafat dapat dicirikan dengan beberapa teks lisan dan salah satunya seperti; "Bukankah pernah kukatakan bahwa satu-satunya yang kita butuhkan untuk menjadi filosof yang baik adalah rasa ingin tahu?" (Gaarder, 2017: 46). Selanjutnya pada teks tulisan lain yang menyebutkan, Sophie merasa semakin tertarik pada filsafat sebab dia dapat mengikuti semua gagasan dengan menggunakan akal 
sehatnya sendiri - tanpa harus mengingat kepada sega. la sesuatu yang telah dipelajarinya di sekolah. Dia memutuskan bahwa fisafat bukanlah sesuatu yang dapat kita pelajari; namum barangkali kita dapat belajar untuk berpikir secara filosofis (Gaarder, 2017: 83). Mungkin Sophie yakin akan hal itu? Dia tidak tahu. Namun, toh, dia baru saja memulai pelajaran filsafatnya (Gaarder, 2017: 91).

Secara sistematis adanya pengenalan filsafat melalui surat kaleng yang berbunyi "Siapa kamu?". Diikuti surat berikutnya dengan pertanyaan "dari mana datangnnya dunia" dan pertanyaan-pertanyaan berikutnya yang tersusun secara sambung menyambung dari awal hingga akhir cerita. Secara sistematis melalui alur maju, di awal muncul ilmu filsafat yang ditandai dengan sejarah filsafat beserta pemahaman para filosof berdasarkan zamannya.

Secara sistemis konteks cerita ditunjukkan denga ilmu filsafat yang diterangkan oleh Alberto Knox melalui teks yang sarat dengan kalimat pengetahuan filsafat seperti dari awal cerita yang kemudian mengalir lebih jauh secara berurutan hingga akhir cerita. Adanya teks-teks yang mencerminkan tentang pembelajaran filsafat terdapat pada tulisan: ... Aku akan mengemukakan garis besar cara orang-orang menyangkut filsafat dari Yunani Kuno hingga zaman kita sekarang. Namun, kita akan menempatkan segala sesuatunya dalam tatanan yang benar.

Karena beberapa filosof hidup pada zaman yang berbeda-dan barangkali dalam kebudayaan yang sama sekali berbeda dengan kita-sebaiknya kita berusaha untuk mengetahui apakah proyek masing-masing filosof tersebut (Gaarder, 2017: 67)

Pada bab-bab berikutnya pembahasan filsafat menceritakan tentang berbagai pemahaman filsafat dan sejarahnya dimulai dari para folosof alam seperti dari Thales, Anaximander, Anaximenes, Heraclitus, dan filosof alam lainnya. Kemudian para filosof zaman pencerahan seperti filosof Athena, filosof zaman Barok, Filosof zaman Pencerahan, hingga ke filosof pada zaman kita saat ini. Beberapa kalimat yang menunjukkan tentang pengetahuan filsafat pada abad pertengahan terdapat pada:

... Setelah wafatnya Muhammad pada 632, baik Timur Tengah maupun Afrika Utara berhasil direbut Islam. Tidak lama kemudian, Spanyol pun menjadi bagian dunia 
kebudayaan Islam. Islam menetapkan Makkah, madinah, Jerusalem, dan Baghdad sebagai kota-kota suci. Dari sudut pandang sejarah kebudayaan, adalah menarik untuk dicatat bahwa bangsa Arab juga mengambil alih kota Helenistik kun, Alexandria. Dengan demikian, banyak di antara ilmu pengetahuan Yunani kuno diwarisi oleh bangsa Arab. Sepanjang Abad Pertengahan, bangsa Arab dangat menonjol dalambidang ilmu pengetahuan seperti matematika, kimia, astronomi, dan ilmu kedokteran. Sekarang juga kita masih menggunakan angaka-angka Arab. Di sejumlah wilayah, kebudayaan Arab lebih unggul daripada kebudayaan Kristen” (Gaarder, 2017: 272).

Tanpa mengurangi esensi dari isi pemahaman tentang filsafat secara sistemis, maka pembuktiannya langsung terlihat pada filsafat abad pertengahan (Renaisans) ke filsafat pada zaman kita saat ini yang lebih banyak membahas tentang faham eksistensialisme dan materialisme yang tercermin dalam kalimat kalimat:

"Satre mengatakan bahwa 'eksistensialisme adalah humanisme'. Dengan itu, yang dimaksudkannya adalah para eksistensialis berangkat dari ketiadaan menuju kemanusiaan itu sendiri. Perlu kutambahakan bahwa humanisme yang diacunya mengambil pandangan yang jauh lebih suram tentang situasi manusia daripada humanisme yang kita temui dalam Renaisans” (Gaarder, 2017: 701).

Kemudian pengungkapan faham materialisme sebagai aliran yang terakhir tercermin dalam kalimat kalimat:

"Kita juga harus mengemukakan aliran terakhir, materialisme, yang juga mempunyai akar sejarah. Banyak ilmu pengetahuan masa kini dapat dilacak kembali kebangkitannya pada masa sebelum Socrates. Misalnya, pencarian 'partikel elementer' yang tak dapat dibagi, yang darinya seluruh materi tersusun. Belum ada orang yang dapat memberikan penjelasan menuskan apakah 'materi' itu. Ilmu pengetahuan modern seperti fisika nuklir dan biokimia begitu terpikat pada masalah yang bagi banyak orang merupakan bagian penting dari filsafat hidup mereka” (Gaarder, 2017: 711).

Novel Dunia Sophie merupakan novel bertema filsafat yang tercermin dari pembicaraan semua tokoh dalam cerita tanpa terkecuali. Kemudian mengaitkan 
kehidupan sehari-hari mereka dengan dunia filsafat yang menjadi bahan pemikiran Sophie sepanjang alur cerita. Permasalahan tidak ada yang melenceng dari dunia filsafat.

\section{- Isi/ungkapan Kedidaktisan}

kedidaktisan yang terdapat dalam isi novel Dunia Sophie diharapakan dapat menemukan kesesuaian antara isi/ungkapan karya sastra dengan tujuan pendidikan nasional dengan acuan: UUSPN No. 20 Tahun 2003. Berdasarkan tujuan kedidaktisan, maka karya sastra yang dikaji diharapkan berisi tentang materi yang dapat mengembangkan potensi dalam diri pembaca. Dari 5 butir tujuan pendidikan nasional, 4 butir memiliki keterkaitan dengan kategori isi/ungkapan kedidaktisan karya novel Dunia Sophie karangan Jostein Gaarder yang kemudian dapat mengembangkan potensi pembaca, di antaranya sebagai berikut.

- Kekuatan spiritual keagamaan yang dapat meningkatkan keimanan, ketakwaan, dan berakhlak mulia. Tujuan dari pendidikan nasional pada butir ini tergambar dalam ungkapan-ungkapan yang menjelaskan tentang penciptaan alam semesta yang dapat menambah keimanan dan ketakwaan pembaca.

- Sehat jasmani. Melalui tema cerita yang menarik namun penting, pembaca akan disuguhi berbagai pemahaman kehidupan yang sebelumnya jarang diketahui manusia pada umumnya. Tema cerita yang bersifat faktual ini dapat meningkatkan kesehatan jasmani dan ruhani pembaca.

- Watak /Kepribadian yang bermartabat, mandiri, kreatif, demokratis, tanggung jawab, dan mampu mengendalikan diri. Kegigihan, ketekunan, kesabaran, rasa ingin tahu, kemadirian, dan kesantunan Sophie sebagai tokph utama memberikan pendidikan dan pengaruh positif kepada pembaca untuk belajar dan meniru watak serta kepribadian tokoh utama.

- Kecerdasan/berilmu. Adapun keterkaitan butir ke-empat yakni di dalam novel ini diterangkan penemuan-penemuan dari berbagai bidang ilmu yang merupakan penemuan penting sepanjang sejarah. Namun, masih disayangkan Gaard lebih banyak mengetengahkan pemikiran para filosof barat dan Eropa dibandingkan filosof dunia 
timur tengah sebagai poros filsafat Islam. Hal tersebut dimungkinkan karena Gaard kurang memiliki referensi yang lengkap tentang dunia Isalam dan para filsafat Islam. Sejauh ini, setidaknya apa yang diungkapkan Gaard adalah telah merepresentasikan seluruh filosof secara umum yang dapat meningkatkan wawasan dan pengetahuan pembaca.

Menemukan dimensi budaya dalam novel Dunia Sophie tidaklah sulit. Dunia Sophie sebagai novel berkualitas dunia yang tak terlepas dari berbagai ragam dimensi kebudayaan dari berbagai tempat di belahan dunia. Sebagaimana Koentjaraningrat (2015) mengemukakan bahwa menemukan dimensi budaya yang termuat dalam karya sastra/film, acuannya adalah dimensi budaya yang lengkap terdiri atas bahasa, ilmu pengetahuan, profesi/pekerjaan, teknologi, seni, sistem/organisasi sosial, dan religi/agama. Contohnya pada abad 4SM di masa Aristoteles, penaklukan Athena oleh Alexander Agung (356- 323 SM) menjadikan dunia timur, India, dan Yunani berhasil dipersatukan dalam sebuah peradaban yang sangat masyur selama tiga abad. "... Suatu peradaban muncul dengan kebudayaan Yunani dan bahasa Yunani memainkan peranan utama. Periode ini, yang berlangsung selama kira-kira 300 tahun, dikenal sebagai Helenisme” (Gaarder, 2017: 209).

"Ilmu pengetahun Helenistik pun terpengaruh oleh campuran pengetahuan berbagai kebudayaan. Kota Alexandria memainkan peranan menentukan di sini sebagai tempat pertemuan antara Timur dan Barat. Sementara Athena tetap merupakan pusat filsafat yang masih menjalankan ajaran-ajaran filsafat Plato dan Aristoteles, Alexandria menjadi pusat ilmu pengetahuan. Dengan perpustakaannya yang sangat besar, kota ini menjadi pusat matematika, astronomi, biologi dan ilmu pengobatan (Gaarder, 2017: 211).

Sesungguhnya, penemuan para pemikir Islam di abad pertengahan, tak kalah penting jika dibandingkan para pemikir barat dan Eropa. Dunia ilmu pengetahuan dari peradaban barat dan Eropa dapat diambil alih oleh para ilmuwan timur tengah (Arab). Ilmu pengetahuan berkembang dengan pesat, dan hal ini kerapkali tak diakui oleh dunia barat. Sayangnya dalam novel ini, informasi tentang masa kejayaan Islam atas penemuanpenemuan dan sumbangannya terhadap kehidupan manusia terkesan ditutupi. Penjelasan 
tentang perkembangan ilmu pengetahuan yang diketemukan para filosof Islam pemaparannya sngat sedikit, bahkan tidak mencapai satu halaman. Tidak ada penyebutan terhadap nama seperti Al-Kindi, Al-Farabi, Ibnu Chaldun, Ibnu Sina, Ibnu Rusyd, AlGhazali, dan filsuf Islam lainnya. Contohnya pada teks-teks lisan berikut ini. "Tidak sepenuhnya. Sebagian Aristoteles dan Plato tetap dikenal. Tetapi kekaisaran Romawi kuno lambat laun terbagi ke dalam tiga kebudayaan yang berbeda. Di Eropa Barat kita mendapat kebudayaan Kristen latin dengan Roma sebagai ibu kotanya. Di Eropa Timur kita bertemu dengan kebudayaan Kristen Yunani dengan Konstantinopel sebagai ibu kotanya. Kota ini mulai disebut dengan nama Yunaninya Bizantium. Oleh karena itu, kita kita membicarakan Abad Pertengahan Bizantium yang bereda dengan Abad Pertengahan Katolik Roma. Namum, Afrika Utara dan Timur Tengah juga telah menjadi bagian kekaisaran Romawi. Daerah ini pada Abad Pertengahanberkembang menjadi kebudayaan Muslim yang menggunakan bahasa Arab. Setelah wafatnya Muhammad pada 632, baik Timur Tengah maupun Afrika Utara berhasil direbut Islam. Tidak lama kemudian, Spanyol pun menjadi bagian dunia kebudyaan Islam. Islam menetapkan Makkah, Madinah, Jerussalem, dan Baghdad sebagai kota-kota suci. Darisudut pandang sejarah kebudayaan adalah menarik untuk dicatat bahwa bangsa Arab juga mengambil alih kota Helenistik kuno, Alexandria. Dengan demikian, banyak di antara ilmu pengetahuan Yunani kuno diwarisi oleh bangsa Arab sangat menonjol dalam bidang ilmu pengetahuan seperti matematika, kimia, astronomi, dan ilmu kedokteran. Sekarang ini kiktia masih menggunakan angka-angka Arab. Di sejumlah wilayah, kebudayaan Arab lebih unggul daripada kebudayaan Kristen" (hal. 272). Untuk dimensi pengetahuan di dalam novel Dunia Sophie dapat kita temukan dalam isi petikan novel sebagaimana paragraf di atas.

Sementara pada dimensi profesi dalam novel ini ditunjukkan dengan penjelasan tentang ayahnya Sophie yang bekerja sebagai pasukan khusus PBB, filosof dan ahli sejarah yaitu Alberto Knox, sebagai dua tokoh kedua yang berpengaruh besar terhadap Sophie dalam mempelajari filsafat. Melalui dua profesi tersebut, Sophie diperkenalkan pula pada dunia filsafat yang lebih luas. 
Dalam novel dunia Sophie, tokoh utamanya menemukan dimensi pengetahuan, menemukan sumber permasalahan/ konflik, dan kemudian menemukan solusinya. Ilmu pengetahuan dimaksud uakni yang dapat mengacu pada ilmu-ilmu sains (metematika, fisika, biologi, kimia, dsb.), sosial (antropologi, sosiologi, ekonomi, geografi, sejarah, dsb.), dan humaniora (linguistik, sastra, filsafat, dsb) (Chase dalam Anshori, 1985).

Kategori dimensi budaya ada pada kebudayaan Athena yang berbentuk peninggalan prasejarah seperti artefak-artefak zaman Yunani Kuno, gedung-gedung tua pada masa kekaisaran Romawi, patung-patung seni pertunjukkan teater di masa Renaisans, bahasabahasa filsafat Yunani Kuno-Timur Tengah, dan lainnya. Adapun dimensi agama ditunjukkan dengan berbagai pemikiran dan penemuan ilmu pengetahuan yang berlandaskan pada hukum-hukum agama. Misalnya dari zaman kegelapan menuju zaman pencerahan yang ditandai dengan penemuan-penemuan ilmu pengetahuan oleh para filosofis Arab pada abad pertengahan. Jika ditinjau secara konseptual ditunjukkan dengan pernyataan-pernyataan para filosof yang terabadikan secara konsep seperti pernyataan pada Empedocles tentang kejadian alam, "alam itu terdiri dari empat unsur, atau "akar" sebagaimana dia mengistilahkan. Keempat akar ini adalah tanah, udara, api, dan air" (Gaarder, 2017: 77). Selanjutnya menampilan Socrates sebagai sosok penuh teka-teki dan membingungkan. Meskipun pemikiran-pemikiran Socrates sepanjang hidupnya tidak pernah dituliskan, akan tetapi Plato sang murid telah mengabadikan setiap perkataan dan pemikirannya Socrates yang ditunjukkan dengan teks lisan, "dia menyimpan "suara Illahi" dalam dirinya (Gaarder, 2017: 119) atau "Socrates menyatakan bahwa dia dituntun oleh suara bathin Illahi, dan bahwa "hati nurani" ini mengatakan kepadanya apa yang benar. "Orang yang mengetahui apa yang baik akan berbuat baik." (Gaarder, 2017: 124). Selanjutnya, "Dengan ini, yang dimaksudkannya adalah bahwa wawasan yang benar akan menuntun pada tindakan yang benar. Dan hanya orang yang bertindak benar sajalah yang dapat menjadi "orang yang berbudi luhur”. Jika kita melakukan kesalahan, itu karena kita tidak tahu” (Gaarder, 2017: 125). Pemikiran Socrates dan penggambaran sosoknya yang diabadikan Plato telah mengilhami para pemikir barat selama hampir 2.500 tahun. Secara prosedural, pemahaman tentang filsafat diterangkan Gaard melalui penceritaan sang filosof, Alberto Knox yang 
berlansung secara bertahap kepada tokoh Sophie. Mulai dari pengenalan filsafat, masa perkembangan filsafat, hingga filsafat abad modern.

Berdasarkan metakognitif, Gaard mampu menuangkan penjelasan-penjelasan tentang ilmu filsafat dalam novel Dunia Sophie dengan bahasa yang lancar, ringan, dan sederhana. Cara penyampain Gaard membuat pembaca dapat menyerap semua ilmu filsafat melalui seluruh aspek kognitif seperti mengingat alur cerita dari awal, mengingat sejarah filsafat yang dimulai dari masa perkembangan hingga abad modern, dan mengingat para filsof dari setiap zaman beserta pemikirannya. Memahami pemikiranpemikiran, penemuan-penemuan, dan gagasan-gagasan filosof melalui dengan bahasanya yang sederhana, bisa membuat pembaca dengan mudah menyerap setiap pemikiran filosof dalam kehidupan sehari-hari.

\section{- Penggunaan Bahasa}

Dalam penggunaan bahasa, Gaard menuangkan bahasa yang ringan, sederhana, lugas, dan tidak bertele-tele, meskipun secara kontekstual novel Dunia Sophi sarat dengan ilmu filsafat yang dianggap cukup berat untuk dipelajari stiap orang. Karena mungkin pula novel ini telah dialihbahasakan kedalam bahasa Indonesia, dan penerjemah buku telah mampu menuangkan bahasa pemikiran, pemahaman, perasaan, serta imajinasi Garrder dengan sangat baik. Selain itu, bahasa Indonesia yang digunakan adalah bahasa Indonesia standar yang mengikuti kaidah struktur/ gramatika bahasa Indonesia, EyD, dan kosakata baku.

Acuan dari penggunaan bahasa adalah karya sastra/film menggunakan bahasa Indonesia standar (mengikuti kaidah struktur/gramatika bahasa Indonesia, EyD, dan kosakata baku), kecuali dialog tokoh disesuaikan dengan konteks penggunaannya agar komunikatif dan dialogis (Sumiyadi, 2015: 5).

\section{- Simpulan}

Karya sastra sebagai salah satu karya seni, dapat dinikmati setiap orang dengan beragam pancaindera. Karya sastra juga memiliki tujuan yang ingin dicapainya yakni karya sastra menjadi sebuah media penyampaian pesan dari pengarang kepada pembaca, termasuk 
menyampaikan berbagai ilmu di luar bidang sastra seperti halnya ilmu filsafat. Filsafat dalam hal ini dalam hal ini merupakan salah satu bidang ilmu yang sangat penting dalam dalam berbagai tararan ilmu lain. Oleh kakrena itu, sangat menarik dan unik ketika ilmu filsafat dikemas ke dalam bentuk karya sastra novel.

Novel Dunia Sophie sebagai sebuah novel bertema filsafat, dimasukkan ke dalam kategori sastra didaktis hibrida yang secara konteskstual merupakan campuran antara sastra didaktis dengan sastra imajinasi. Novel ini banyak menyampaikan pembelajaran tentang ilmu filsafat, selain itu novel ini mendampingkan filsafat dengan ruang imajinasi pembaca dalam alur cerita.

Novel Dunia Sophie dianalisis dengan menggunakan pedoman analisis teknik dengan cara mengungkapkan, teknik analisis isi ungkapan, dan teknik analisis penggunaan bahasa. Berdasarkan kajian kedidaktisan, novel Dunia Sophie sarat akan kedidaktisan sebuah karya sastra. Selain itu, secara konteks novel Dunia Sophie mengandung unsur metakognitif yang layak untuk dijadikan sebagai salah satu media pembelajaran pada mata kuliah filsafat dan mata kuliah bidang sastra.

\section{DAFTAR PUSTAKA}

Abrams, M.H. 1999. A Glossary of Literary Terms. New York: Holt, Rinehart \& Winston.

Anderson, Lorin W. \& Krathwohl, David R. 2010. Kerangka Landasan untuk Pembelajaran, Pengajaran, dan Asesmen. (Terjemahan Agung Prihantoro). Yogyakarta: Pustaka Pelajar.

Anshari, Endang Sefuddin. 1985. Ilmu, Filsafat, dan Agama. Surabaya: PT Bina Ilmu.

Badan Pengembangan dan Pembinaan Bahasa Kementerian Pendidikan dan Kebudayaan. 2017. Kamus Besar Bahasa Indonesia Edisi Kelima. Jakarta: Balai Pustaka.

Gaarder, Jostein. 2017. Dunia Sophie, Sebuah Novel Filsafat. Bandung: Penerbit Mizan.

Koentjaraningrat. 2015. Kebudayaan, Mentalitas, dan Pembangunan. Jakarta: Gramedia. 
Poedjawiyatna, I.R. 1974. Pembimbing ke Arah Alam Filsafat. Pembangunan: Djakarta.

Semi, Atar. 1989. Kritik Sastra. Bandung: Angkasa.

Slavin, Robert E. 2011. Cooperative Learning, Teori, Riset, dan Praktik. Bandung: Nusa Media.

Oemardjo, Jakob dan Saini K.M. 1988. Apresiasi Kesusatraan. Jakarta: Gramedia.

Stanton, Robert.2007. Teori Fiksi Robert Stanton. (Terjemahan Sugihastuti dan Rossi Abi Al Irsyad). Yogyakarta: Pustaka Pelajar.

Sumiyadi dkk (2015) Kajian Bandingan Kedidaktisan Karya Sastra Indonesia dengan Film Adaptasinya sebagai Upaya Menyususn Buku Suplemen Mata Pelajaran Bahasa Indonesia yang Sesuai dengan Kurikulum 2013. Penelitian Unggulan Perguruan Tinggi. Universitas Pendidikan Indonesia,

Undang-Undang Sistem Pendidikan Nasional Nomor 20 Tahun 2003.

Wellek, Rene \& Warren, Austin. 1989. Teori Kesusastraan. PT. Gramedia: Jakarta.

Zaidan, Abdul Rozak dkk. 2004. Kamus Istilah Sastra. Jakarta: Balai Pustaka. 